\title{
Prediction equations for maximal respiratory pressures of Brazilian adolescents
}

\author{
Raquel E. F. Mendes ${ }^{1}$, Tania F. Campos ${ }^{1}$, Thalita M. F. Macêdo ${ }^{1}$,
} Raíssa 0. Borja ${ }^{1}$, Verônica F. Parreira ${ }^{2}$, Karla M. P. P. Mendonça ${ }^{1}$

\begin{abstract}
Background: The literature emphasizes the need for studies to provide reference values and equations able to predict respiratory muscle strength of Brazilian subjects at different ages and from different regions of Brazil. Objectives: To develop prediction equations for maximal respiratory pressures (MRP) of Brazilian adolescents. Method: In total, 182 healthy adolescents (98 boys and 84 girls) aged between 12 and 18 years, enrolled in public and private schools in the city of Natal-RN, were evaluated using an MVD300 digital manometer (Globalmed ${ }^{\circledR}$ ) according to a standardized protocol. Statistical analysis was performed using SPSS Statistics 17.0 software, with a significance level of 5\%. Data normality was verified using the Kolmogorov-Smirnov test, and descriptive analysis results were expressed as the mean and standard deviation. To verify the correlation between the MRP and the independent variables (age, weight, height and sex), the Pearson correlation test was used. To obtain the prediction equations, stepwise multiple linear regression was used. Results: The variables height, weight and sex were correlated to MRP. However, weight and sex explained part of the variability of MRP, and the regression analysis in this study indicated that these variables contributed significantly in predicting maximal inspiratory pressure, and only sex contributed significantly to maximal expiratory pressure. Conclusion: This study provides reference values and two models of prediction equations for maximal inspiratory and expiratory pressures and sets the necessary normal lower limits for the assessment of the respiratory muscle strength of Brazilian adolescents.
\end{abstract}

Keywords: adolescent; respiratory muscles; spirometry; muscle strength; reference values; movement.

\section{HOW TO CITE THIS ARTICLE}

Mendes REF, Campos TF, Macêdo TMF, Borja RO, Parreira VF, Mendonça KMPP. Prediction equations for maximal respiratory pressures of Brazilian adolescents. Braz J Phys Ther. 2013 May-June; 17(3):218-226. http://dx.doi.org/10.1590/ S1413-35552012005000086

\section{Introduction}

The normal values and prediction equations available for maximal respiratory pressures (MRP) vary between studies due to differences in sample selection procedures, as well as geographical, social and anthropometric variables or the variability of equipment and techniques employed ${ }^{1,2}$.

The prediction equations available in the literature ${ }^{1,3-6}$ demonstrate that the variables weight, age, height and sex have an influence on MRP values. However, there is no inter-study agreement on which of these variables are associated to MRPs. Thus, many studies ${ }^{1,3-12}$ have been performed in an attempt to establish normal values and/or prediction equations for respiratory muscle strength that consider anthropometric factors in different populations.

In Brazil, the Brazilian Pulmonology and Tuberculosis Society recommends research concerning pulmonary function parameters, including
MRP, to establish reference values for the different age groups and ethnicities comprising the Brazilian population $^{12,13}$.

Recent studies have provided prediction equations for maximal respiratory pressures in Brazilian children $^{14}$ and adults ${ }^{6}$. However, Freitas et al. ${ }^{15}$ reviewed studies containing prediction equations and reference values from childhood to adolescence, observing the nonexistence of these parameters in Brazilian teenagers. This is significant, given that the international literature has already reported on this issue $e^{4,5,7-11}$.

In 1984, Wilson et al. ${ }^{4}$ evaluated 235 British Caucasian children between 7 and 17 years old and found that for both sexes, Maximal Inspiratory Pressure (MIP) was associated with weight and Maximal Expiratory Pressure (MEP) was associated

\footnotetext{
${ }^{1}$ Programa de Pós-graduação em Fisioterapia, Departamento de Fisioterapia, Universidade Federal do Rio Grande do Norte (UFRN), Natal, RN, Brasil

${ }^{2}$ Programa de Pós-graduação em Ciências da Reabilitação, Departamento de Fisioterapia, Universidade Federal de Minas Gerais (UFMG), Belo Horizonte, MG, Brasil

Received: 11/04/2012 Revised: 22/10/2012 Accepted: 23/11/2012
} 
with age, confirming that weight and age were predictors of MRP for this population.

Subsequently, Domènech-Clar et al..$^{5}$ assessed 392 Spanish individuals aged between 8 and 17 years. The authors observed that in addition to weight and age, height also influenced MRP, and included this variable in prediction equations for MRP in children and adolescents.

Several studies involving adolescents have reported differences between variables considered determinants in quantifying respiratory muscle strength $^{4,5,7-11}$. Some authors ${ }^{4,8}$ observed a positive trend related to age, whereas others did not observe this effect ${ }^{9}$. In addition, related to this population, studies such as those conducted by Schrader et al. ${ }^{16}$ and Domènech-Clar et al. ${ }^{5}$ demonstrated that boys had higher MIP and MEP than girls. Wagener et al. ${ }^{8}$ also demonstrated that in the prepubertal age, this difference is smaller, and from 13 years and older, this difference increases. These may be related to the hormonal ${ }^{11}$, physiological, psychological and somatic alterations characteristic of this age group ${ }^{17}$.

As such, given the clear influence of anthropometric and ethnic characteristics on respiratory muscle strength, in addition to the need for national reference values and equations capable of predicting MRP in adolescents, this study aimed to determine normal values and prediction equations for MIP and MEP in Brazilian teenagers.

\section{- Method}

This was an observational, cross-sectional descriptive study ${ }^{18}$ approved by the Research Ethics Committee of the Universidade Federal do Rio Grande do Norte (UFRN), Natal, RN, Brazil (protocol 278/2009). All the adolescents and their legal guardians gave written informed consent, and the research was conducted in accordance with criteria from the Declaration of Helsinki.

Sample size was calculated using the formula to estimate the mean proposed by Lima et al. ${ }^{19}$. A significance level of 5\% was established, and the power of the test was $95 \%$. Sample size was calculated for 182 adolescents, 14 boys and 12 girls for each age assessed. The teenagers were randomly selected at 20 schools encompassing the four zones of the city of Natal (Figure 1). The standard deviation and error estimate used were those determined by Wilson et al. ${ }^{4}$.

Those considered eligible to participate were teenagers of both sexes, aged between 12 and 18 years, eutrophic $\left(3^{\text {rd }}\right.$ percentile to less than the $85^{\text {th }}$ percentile $)^{20}$ and enrolled in public or private elementary and middle schools in the municipality of Natal, Brazil. Participants could not present with diagnosed chronic cardiovascular, pulmonary or neuromuscular diseases; reported use of medications that might influence respiratory muscle strength ${ }^{21}$; neurological impairment or incomprehension of assessment instructions ${ }^{2,21}$; recent trauma of the upper airways, chest of abdomen; acute middle ear problems, abdominal hernia, glaucoma or retinal detachment $^{2}$; fever in the last 3 weeks ${ }^{1,2}$ or flu in the week prior to the procedure; history of smoking ${ }^{2}$; evident chest deformity ${ }^{2}$; or a score of 7 or higher on the standardized questionnaire of the American Thoracic Society and Division of Lung Diseases ATS-DLD-78-C $\mathrm{C}^{22}$. This information was obtained via questionnaires filled out by parents or guardians.

Individuals excluded were those unable to perform the necessary procedures and those who declined to participate; exhibited acute respiratory tract disease during the collection period; missed class during the evaluation period at their school; presented with a nutritional diagnosis of underweight, overweight or obesity according to Ministry of Health ${ }^{19}$ guidelines; displayed values lower than $80 \%$ of those predicted for Peak Expiratory Flow (PEF), Forced Vital Capacity (FVC), Forced Expiratory Volume (FEV), Forced Expiratory Volume in the first second $\left(\mathrm{FEV}_{1}\right)$ and the $\mathrm{FEV}_{1} / \mathrm{FVC}$ ratio, as well as values less than $70 \%$ of those predicted for mean Forced Expiratory Flow between 25 and $75 \%$ of the FVC curve $\left(\mathrm{FEF}_{25-75}\right)$ - in accordance with $\mathrm{ATS}^{23}$ criteria. The measures proposed by pulmonary function guidelines were used as spirometric reference values $^{24}$. Also excluded were adolescents who did not acceptably perform at least 3 of a maximum of 9 manovacuometer maneuvers ${ }^{5}$ (without leakage, lasting at least 2 seconds $^{2}$ and sustained for 1 second ${ }^{25}$ ), of which at least two were reproducible (with values that did not differ by more than $10 \%$ ), with the larger value used. Figure 1 describes the sample selection.

Eligible teenagers were submitted to anthropometric assessment to measure body weight and height. Anthro Plus ${ }^{26}$ software from the World Health Organization (WHO) was used to evaluate nutritional status. A diagnosis is automatically provided once anthropometric data are fed into the program. Eutrophic adolescents were referred for spirometry.

Spirometry was performed using a handheld One Flow FVC digital spirometer (Clemente Clark International - England) attached to a sterile 


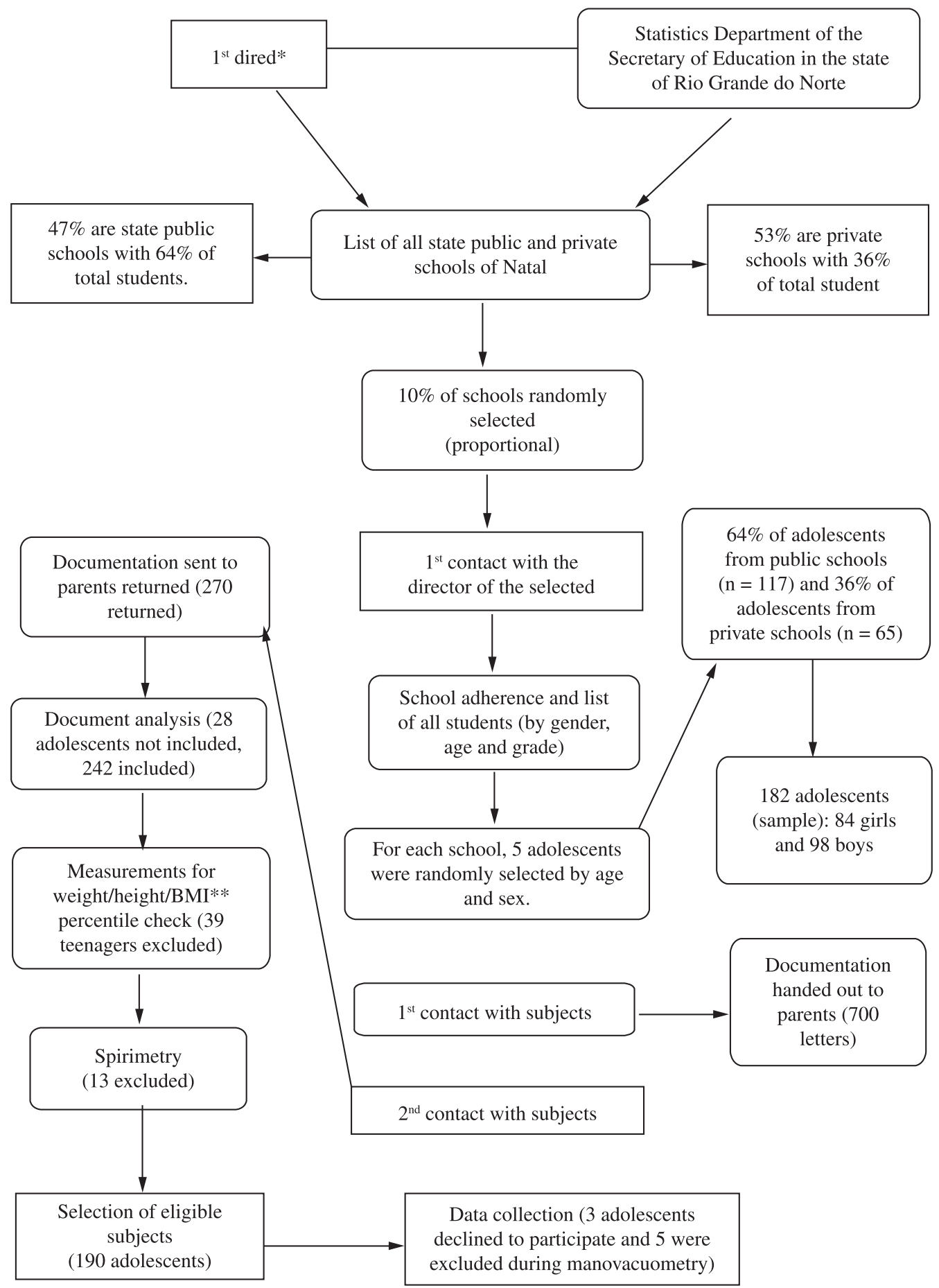

$* 1^{\text {st }}$ Regional Board of Education/**BMI: Body Mass Index.

Figure 1. Flowchart of subject selection.

mouthpiece and bacterial filter (VIASYS Respiratory Care MicroGard Filter), both of which were disposable. To prevent air leakage, the subjects used a nose clip and were instructed to adequately adjust their lips around the mouthpiece. Because this was an effort-dependent test, the participants received verbal encouragement from the same examiner.

The subjects remained seated with their heads in a neutral position and back against a chair, their chests forming a $90^{\circ}$ with their hips and arms resting on 
their legs. In accordance with ATS/ERS guidelines ${ }^{27}$, adolescents were instructed to perform one maximum inspiration (indicated by a predetermined gesture), close their mouth firmly around the mouthpiece and, following a minimum pause, make a vigorous maximum expiration. Because this was an effortdependent test, the participants received verbal encouragement from the same examiner.

Maneuvers were performed in accordance with the reproducibility and acceptability criteria recommended by the $\mathrm{ATS}^{23}$. A minimum of three and maximum of eight maneuvers were executed. Of these, three were acceptable, and the best two did not exhibit a maximum difference of $0.150 \mathrm{~L}$ between them, with the better of the two tests chosen. In addition, to select the best values, $\mathrm{FVC}$ and $\mathrm{FEV}_{1}$ were required to be the highest and not necessarily from the same curve and forced expiratory flow between $25 \%$ and $75 \%$ of FVC (FEF25-75\%) that were chosen from the curve with the greatest sum of $\mathrm{CVF}$ and $\mathrm{VEF}_{1}{ }^{23}$. A one-minute rest was permitted between each maneuver.

After 10 minutes of rest, the same examiner conducted a manometric assessment using an MVD300 digital manometer (Globalmed ${ }^{\circledR}$, Porto Alegre - RS, Brazil) and disposable biological filter (Vida Tecnologia Biomédica, São Paulo - SP, Brazil). A Rescal adaptor was attached to the filter, which contained a hole to connect the system with the ambient air. This was coupled to a rigid and flattened plastic mouthpiece (Globalmed ${ }^{\circledR}$, Porto Alegre - RS, Brazil) with a 2-mm wide hole on its upper surface (to dissipate additional pressure caused by the contraction of facial muscles ${ }^{3}$ ). The evaluation was performed with the manometer connected to a laptop. The computer software provided the subject with visual feedback, and auditory feedback was given by the examiner.

The participants were told to sit comfortably (as described for spirometry) and properly adjust their lips around the mouthpiece. To avoid air leakage, a nose clip was used for all measurements.

Maneuvers were verbally explained and demonstrated by the examiner. As previously mentioned, because this was an effort-dependent test, the examiner provided verbal encouragement during assessment. MRP measurement was performed in accordance with the method proposed by Souza ${ }^{2}$.

Initially, adolescents randomly selected the first MRP to be assessed. To assess MIP, teenagers were instructed to exert maximum inspiratory effort starting from residual volume. To evaluate MEP, the subjects were asked to exert maximum expiratory effort starting from total lung capacity ${ }^{2,25}$. At this moment, the examiner supported the subject's cheeks with both hands to ensure minimum loss of pressure due to complacency of the oral cavity ${ }^{28}$.

As suggested by Domènech-Clar et al..$^{5}$, a maximum of nine maneuvers were performed for each MRP assessment. Of these, at least three had to be acceptable, from which a minimum of two were required to be reproducible. The better of these two values was selected; however, the last measurement could not be the highest, and another measurement was taken when this occurred. A one-minute rest was permitted between each maneuver, with five minutes allowed between the MIP and MEP assessment.

Several authors ${ }^{1,3,7,9,12,21}$ have used sustained pressure to evaluate the strength of respiratory muscles. Nevertheless, the equipment used in this investigation only directly supplies peak pressure values. As such, sustained pressure values were determined by examining the pressure versus time curve provided by the manometer software. These values were then exported to Microsoft Office Excel 2007 and analyzed according to the protocol proposed by Borja ${ }^{14}$.

\section{Data analysis}

Data were analyzed using SPSS statistics software version 17.0, with a significance level of 5\%. Data normality was verified by the Kolmogorov-Smirnov test. Descriptive statistics are expressed as the mean and standard deviation. One-way analysis of variance (ANOVA), followed by the Bonferroni post hoc test, was used to determine whether there was a significant difference in the MRPs between the 7 ages assessed. Non-paired Student's t-test was applied to verify inter-gender differences.

Prediction equations were constructed via multiple linear regression analysis to identify predictor variables of MRP in healthy adolescents. Prior to this, Pearson's correlation test was performed to verify the association between dependent (MIP and MEP) and independent variables (age, sex, weight and height). Anthropometric variables exhibiting significant correlation with MRP were added to the linear regression model one by one, in descending order of the correlation coefficient and significance level $^{29}$ (stepwise forward). Residual analysis was conducted to confirm normality, linearity and equal variance of the regression model. The lower limit of normal (LLN) was calculated by subtracting a value two times greater than the standard deviation of the measurements from mean $\mathrm{MRP}^{2}$. 


\section{Results}

A total of 700 questionnaires were handed out at 20 participating schools. Of the 270 that were returned, 28 teenagers were not included in the sample for non-compliance with one of the inclusion criteria. Among the 242 adolescents selected, 60 were excluded (3 refused to take part, 39 were not classified as eutrophic, 13 did not meet criteria established by spirometry and 5 were unable to perform acceptable and reproducible manovacuometer maneuvers among the maximum number of nine measurements), resulting in a total sample of 182 subjects.

The data exhibited normal distribution for age, weight, height and Body Mass Index (BMI), except for females. Table 1 describes the anthropometric variables, expressed as the mean and standard deviation, according to age and sex.

ANOVA indicated no significant difference between age and MIP ( $\mathrm{p}=0.18)$ and MEP $(\mathrm{p}=0.15)$.
Table 2 depicts the means obtained in girls and boys for the MRP and Lower Limits of Normal (LLN) of the teenagers assessed. A comparison of MRP between sexes indicated that both MIP and MEP of male adolescents were significantly higher $(p=0.00)$ than those of females.

Table 3 shows the correlation matrix, demonstrating a significant decreasing correlation between MIP with sex, weight and height and for MEP with sex, height and weight. In accordance with the descending order of significance, these were added one by one to the model, observing the behavior of the model as each one was introduced. To perform the analysis, the variable sex was categorized. The regression analysis showed that the variables sex and weight contributed significantly to predicting MIP, whereas only sex contributed significantly to MEP.

Table 4 shows the proposed prediction equations for MRP in Brazilian adolescents.

Table 1. Description of anthropometric variables, expressed as the mean and standard deviation, according to age and sex.

\begin{tabular}{|c|c|c|c|c|}
\hline Age (years) & Sex & Weight (Kg) & Height (m) & BMI $\left(\mathrm{Kg} / \mathrm{m}^{2}\right)$ \\
\hline \multirow[t]{2}{*}{12} & Female $(n=12)$ & $46.33 \pm 9.80$ & $1.56 \pm 0.08$ & $18.69 \pm 2.57$ \\
\hline & Male $(\mathrm{n}=14)$ & $42.93 \pm 6.12$ & $1.54 \pm 0.08$ & $17.92 \pm 2.26$ \\
\hline \multirow[t]{2}{*}{13} & Female $(n=12)$ & $44.75 \pm 6.60$ & $1.58 \pm 0.05$ & $17.72 \pm 2.32$ \\
\hline & Male $(n=14)$ & $54.00 \pm 6.96$ & $1.66 \pm 0.05$ & $19.41 \pm 1.74$ \\
\hline \multirow[t]{2}{*}{14} & Female $(n=12)$ & $49.33 \pm 4.79$ & $1.59 \pm 0.04$ & $19.41 \pm 2.29$ \\
\hline & Male $(n=14)$ & $54.14 \pm 9.72$ & $1.66 \pm 0.08$ & $19.50 \pm 1.96$ \\
\hline \multirow[t]{2}{*}{15} & Female $(\mathrm{n}=12)$ & $53.50 \pm 7.45$ & $1.62 \pm 0.07$ & $18.46 \pm 6.36$ \\
\hline & Male $(\mathrm{n}=14)$ & $57.07 \pm 14.23$ & $1.72 \pm 0.06$ & $18.71 \pm 5.49$ \\
\hline \multirow[t]{2}{*}{16} & Female $(n=12)$ & $52.50 \pm 7.11$ & $1.61 \pm 0.05$ & $20.06 \pm 2.70$ \\
\hline & Male $(\mathrm{n}=14)$ & $64.14 \pm 8.52$ & $1.74 \pm 0.07$ & $20.95 \pm 1.87$ \\
\hline \multirow[t]{2}{*}{17} & Female $(n=12)$ & $54.25 \pm 10.92$ & $1.62 \pm 0.06$ & $20.45 \pm 3.15$ \\
\hline & Male $(n=14)$ & $68.07 \pm 8.68$ & $1.74 \pm 0.07$ & $22.53 \pm 1.94$ \\
\hline \multirow[t]{2}{*}{18} & Female $(n=12)$ & $54.75 \pm 7.94$ & $1.60 \pm 0.08$ & $19.44 \pm 6.39$ \\
\hline & Male $(n=14)$ & $66.64 \pm 11.14$ & $1.71 \pm 0.07$ & $21.39 \pm 2.96$ \\
\hline
\end{tabular}

BMI: body mass index.

Table 2. Normal values and lower limit of normal for maximal respiratorypressures according to sex.

\begin{tabular}{lcc}
\hline & Female $(\mathbf{n}=\mathbf{8 4})$ & Male $(\mathbf{n = 9 8})$ \\
MIP $\left(\mathrm{cmH}_{2} 0\right)$ & $75.33 \pm 22.21$ & $86.86 \pm 24.94$ \\
$\operatorname{MEP}\left(\mathrm{cmH}_{2} 0\right)$ & $104.65 \pm 26.87$ & $121.08 \pm 29.77$ \\
LLN MIP $\left(\mathrm{cmH}_{2} 0\right)$ & 30.91 & 36.98 \\
LLN MEP $\left(\mathrm{cmH}_{2} 0\right)$ & 50.91 & 61.84 \\
\hline
\end{tabular}

MIP: maximal inspiratory pressure; MEP: maximal expiratory pressure; LLN: lower limit of normal.
Table 3. Correlation matrix between maximal respiratory pressures and anthropometric variables.

\begin{tabular}{lcccc}
\hline & \multicolumn{2}{c}{ MIP } & \multicolumn{2}{c}{ MEP } \\
& $\mathbf{r}$ & $\mathbf{p}$ valor & $\mathbf{R}$ & p valor \\
Sex & 0.509 & 0.00 & 0.527 & 0.00 \\
Age (years) & 0.070 & 0.35 & 0.070 & 0.34 \\
Weight (Kg) & 0.320 & 0.00 & 0.264 & 0.00 \\
Height (m) & 0.266 & 0.00 & 0.258 & 0.00 \\
\hline
\end{tabular}

MIP: maximal inspiratory pressure; MEP: maximal expiratory pressure; r: correlation coefficient. 
Table 4. Prediction equations for maximal respiratory pressure in Brazilian adolescents.

\begin{tabular}{lccll}
\hline & Prediction equations & $\mathbf{R}^{2}$ adjusted & SEE & \multicolumn{1}{c}{ CI95\% } \\
MIP $\left(\mathrm{cmH}_{2} 0\right)$ & $53.8+26.1(\mathrm{~S})+0.4(\mathbf{W})$ & 0.27 & 24.51 & $35.3+18.4(\mathrm{~S})+0.075(\mathbf{W})$ \\
$\mathrm{MEP}\left(\mathrm{cmH}_{2} 0\right)$ & $86.85+34.22(\mathrm{~S})$ & 0.27 & 27.6 & $80.9+26.1(\mathrm{~S})$ \\
\hline
\end{tabular}

MIP: maximal inspiratory pressure; MEP: maximal expiratory pressure; $\mathrm{R}^{2}$ adjusted: adjusted coefficient of determination; SEE: standard error of estimate; C195\%: 95\% confidence interval; $\mathrm{S}$ (sex): Female $=0$ and Male=1; W=weight $(\mathrm{kg})$.

\section{Discussion}

In agreement with previous research involving teenagers ${ }^{4,5,8-10,30}$, the MRP measurements recorded in this study indicate greater respiratory muscle strength among boys. The same finding has also been reported in other investigations of children ${ }^{4,7,10,14}$ and adults ${ }^{3,4,6,12}$. The difference in body weight between the sexes has long explained and confirmed this finding because it is known that male muscle mass is greater than that of females ${ }^{31}$.

The variables weight and height displayed a positive yet weak correlation with MRP. However, age did not influence the respiratory muscle strength of the adolescents assessed. To date, there is no consensus regarding the ability of these variables to predict respiratory muscle strength in teenagers. Leech et al. ${ }^{30}$ observed a positive association between weight and MRPs in both sexes, whereas Wilson et al. ${ }^{4}$ reported that weight was only positively correlated with the MIP of children and adolescents. These authors also demonstrated a correlation between MEP and age. Subsequently, DomènechClar et al. ${ }^{5}$ observed that the MIP of boys and girls and the MEP of boys were predicted by height, age and weight, although they were not capable of predicting the respiratory muscle strength of girls.

With respect to the variable weight, studies conducted with obese individuals ${ }^{32,33}$ demonstrated a decreased functional residual capacity and total lung capacity and thoracoabdominal compliance, whereas MRP values were normal, except in obese individuals who presented with obesity hyperventilation syndrome. A later study, involving eutrophic and grade 1 overweight/obese teenagers, corroborated earlier findings because MRP measures in individuals with grade 1 overweight/obesity were significantly higher than those observed in eutrophic adolescents ${ }^{34}$. The findings of Rasslan et al. ${ }^{35}$ further substantiate the effect of the association between increased BMI and enhanced lung function on muscle function. According to Ray et al. ${ }^{36}$, this effect is related to the compensatory increase in inspiratory capacity as a response to greater ability and inspiratory muscle effort to compensate, at least temporarily, the weight of abdominal contents and the thoracic wall. It is important to underscore the prediction effect that a small weight gain can exert on respiratory muscle strength. This is not only reflected in an increase of adipose tissue but also in a gain of bone and muscle mass, primarily in children and teenagers ${ }^{37}$.

In contrast with the findings of previous research involving Brazilian children ${ }^{14}$ and adults ${ }^{1,6}$, the present study found no significant difference in MRP between the ages of 12 and 18 years for both sexes. In males, there was a linear increase, but not significant, for PRM from 12 to 14 years for MIP and from 12 to 15 years for MEP. In females, similar behavior was observed from 12 to 15 years for MIP and from 12 to 13 years for MEP. The lack of a significant difference in MRP between the age groups assessed suggests that respiratory muscle strength at 12 years old may already be similar to that of an adult. These findings partially corroborate those previously reported by Gaultier and Zinman ${ }^{7}$, who evaluated respiratory muscle strength in a sample of Caucasian Americans aged from 7 to 13 years old. The authors observed that MRP in this age group increased linearly with age, and this growing strength occurred differently in males and females. They compared the measurements obtained with those of healthy adults and confirmed that girls achieved these same values for both pressures at approximately 11 to 12 years old, whereas in boys this was only observed for MIP. Finally, the authors concluded that for males, MEP may continue to rise during adolescence.

However, when Matecki et al. ${ }^{11}$ assessed the MRP of 44 healthy boys subdivided into three groups (prepubescent, pubescent and postpubescent), they observed that MIP increased significantly between the ages of 11 and 17 years and MEP increased from 11 to 15 years old. The authors concluded that the pre- or post-developmental phase may modify the influence of age on MRP values, thus demonstrating that anthropometric characteristics may play a small role in determining respiratory muscle strength. Santiago et al. ${ }^{38}$ later corroborated these results by stating that in overweight/obese children and adolescents, sex, growth factors and hormones may have a greater influence on MRP values than anthropometric variables. 
It is important to note that in the present study, which used a sample consisting of adolescents, the slight increase in MIP and MEP observed during the growth phase may be related to the physiological changes that occur in puberty ${ }^{11}$. During this phase of life, the size and mass of respiratory muscles increases, chest dimensions and the mechanical properties of the respiratory system change, and the central nervous systems matures, possibly influencing muscle contraction ${ }^{39}$.

The main objective of this study was to propose prediction equations for MRP in Brazilian adolescents. To that end, multiple linear regression was applied, and the prediction power was evaluated using the coefficient of determination $\left(\mathrm{R}^{2}\right)$. In contrast to previous investigations $s^{4.5}$, we were unable to develop a prediction equation for each sex, likely because the predictors of respiratory muscle strength for this age group display similar behavior for both sexes.

This finding was also reported by Koechlin et al. ${ }^{40}$, who assessed teenagers of both sexes in the pre- and peripubertal phases, suggesting that although the sex hormones are different, they exhibit similar behavior. Borja ${ }^{14}$ also aimed at developing prediction equations for MRP in Brazilian children, but the authors were unable to construct specific equation models for each sex. Thus, two prediction equations for respiratory muscle strength were determined. The prediction equation for MIP includes the independent variables weight and sex, and the prediction equation for MEP includes only the variable sex. This was categorized.

The prediction power of equations proposed in this study was $27 \%$ for both pressures, demonstrating that the anthropometric variables sex and weight responded in part to MIP and MEP variability. The same occurred for the prediction equations proposed by Wilson et $\mathrm{al}^{4}{ }^{4}\left(\mathrm{R}^{2}=15.8 \%\right.$ and $10.8 \%$ for MIP in males and females, respectively) and DomènechClar et al..$^{5}\left(\mathrm{R}^{2}=21 \%\right.$ and $28 \%$ for MIP and MEP in females).

Previous studies of Brazilian adults ${ }^{1,6}$ and children ${ }^{14}$ with the purpose of determining prediction equations for MRP also used a mathematical model whose prediction power was denoted by the value of $\mathrm{R}^{2}$.

Regardless of the $\mathrm{R}^{2}$ value determined in this or other research ${ }^{1,4,5,8,14}$, the independent variables weight, sex, height and age only partially explained MRP variability. These findings suggest there are other factors - sex hormones ${ }^{11}$, growth hormones ${ }^{8}$, physical activity level ${ }^{1}$, spirometric variables ${ }^{7}$, and percentage of lean muscle mass ${ }^{1}$ - that play an important role in predicting the respiratory muscle strength of healthy children, adolescents and adults.

Lower limits of normal (LLN) ${ }^{41}$ have been increasingly used to compensate for the wide variation in normal MRP values proposed by studies and primarily to avoid a false positive interpretation of muscle weakness. In accordance with this trend, the present study also provides the LLN for the MRP values of healthy adolescents.

It is important to underscore that when individuals are unable to exceed the LLN for their age group, they have a maximum likelihood of $2.5 \%$ of achieving the value obtained for normal MIP and/or MEP ${ }^{2}$. This has great clinical relevance, given that, in neuromuscular diseases ${ }^{42,43}$, reduced respiratory muscle strength can be detected prior to the decrease in lung volume ${ }^{44}$.

During adolescence, the changes that presumably occur up to physiological maturity are influenced by sex hormones, which may directly or indirectly interfere with respiratory muscle strength ${ }^{11,45}$. Silva et al. ${ }^{45}$ analyzed the changes in PEF and respiratory muscle strength during the menstrual cycle of healthy women and recorded a correlation between estradiol and progesterone levels, indicating a positive influence of female sex hormones on respiratory muscle strength in the luteal phase. The male hormone testosterone, also found in women at lower levels, stimulates respiratory $\operatorname{control}^{46}$. Thus, a limiting factor in the present study was the impossibility of performing a hormonal assessment of participants. Therefore, we suggest a longitudinal study evaluating the MRP of subjects from pre- to post-puberty, including a hormonal evaluation for both sexes.

It is important to determine MRP parameters because this method, compared with the pulmonary function test, is more sensitive than the latter in assessing and monitoring respiratory muscle impairment. Furthermore, this test exhibits low intraindividual variability, which allows followup of lung and extralung diseases in the same individual ${ }^{2,5,11}$.

Thus, the findings of this study fill a gap in terms of what parameters to assess the MRP values of Brazilian teenagers because the study proposes reference values and two prediction equations for maximal inspiratory and expiratory pressure, establishing the lower limit of normal for these variables. Taken together, this information will serve as indispensable parameters that facilitate a thorough assessment of respiratory muscle strength in Brazilians aged between 12 and 18 years, allowing diagnosis and follow-up of respiratory muscle weakness in individuals with different disorders. 


\section{References}

1. Neder JA, Andreoni S, Lerario MC, Nery LE. Reference values for lung function tests. II. Maximal respiratory pressures and voluntary ventilation. Braz J Med Biol Res. 1999;32(6):719-27. PMid:10412550. http://dx.doi. org/10.1590/S0100-879X1999000600007

2. Souza RB. Pressões respiratórias estáticas máximas. J Pneumol. 2002;28 Suppl 3:155-65.

3. Black LF, Hyatt RE. Maximal respiratory pressures: normal values and relationship to age and sex. Am Rev Respir Dis. 1969;99:696-702. PMid:5772056.

4. Wilson SH, Cooke NT, Edwards RHT, Spiro SG. Predicted normal values for maximal respiratory pressures in caucasian adults and children. Thorax. 1984;39:535-38. PMid:6463933 PMCid:459855. http://dx.doi.org/10.1136/ thx.39.7.535

5. Domènech-Clar R, López-Andreu JA, Compte-Torrero L, De Diego-Damiá A, Macián-Gisbert V, Perpiñá-Tordera $\mathrm{M}$, et al. Maximal static respiratory pressures in children and adolescents. Pediatr Pulmonol. 2003;35:126-32. PMid:12526074. http://dx.doi.org/10.1002/ppul.10217

6. Costa D, Gonçalves HA, Lima LP, Ike D, Cancelliero KM, Montebelo MI. New reference values for maximal respiratory pressures in the Brazilian population. J Bras Pneumol. 2010;36(3):306-12. PMid:20625667. http:// dx.doi.org/10.1590/S1806-37132010000300007

7. Gaultier C, Zinman R. Maximal static pressures in healthy children. Respir Physiol. 1983;51:45-61. http://dx.doi. org/10.1016/0034-5687(83)90101-9

8. Wagener JS, Hibbert ME, Landau LI. Maximal respiratory pressures in children. Am Rev Respir Dis. 1984;129:873875. PMID:6721285

9. Smyth RJ, Chapman KR, Rebuck AS. Maximal inspiratory and expiratory pressures in adolescents: normal values. Chest. 1984;86:568-72. PMid:6478896. http://dx.doi. org/10.1378/chest.86.4.568

10. Szeinberg A, Marcotte JE, Roizin H, Mindorff C, Englad S, Tabachnik E, et al. Normal values of maximal inspiratory and expiratory pressures with a portable apparatus in children, adolescents, and young adults. Pediatr Pulmonol. 1987; 3:255-8. PMid:3658531. http://dx.doi. org/10.1002/ppul.1950030411

11. Matecki S, Prioux J, Jaber S, Hayot M, Prefaut C, Ramonatxo M. Respiratory pressures in boys from 11-17 years old: a semilongitudinal study. Pediatr Pulmonol. 2003;35:368-74. PMid:12687594. http://dx.doi. org/10.1002/ppul.10274

12. Parreira VF, França DC, Zampa CC, Fonseca MM, Tomich GM, Britto RR. Pressões respiratórias máximas: valores encontrados e preditos em indivíduos saudáveis. Rev Bras Fisioter. 2007;11(5):36-68. http://dx.doi. org/10.1590/S1413-35552007000500006

13. Pereira CAC. Espirometria. J Pneumol. 2002; 28 Suppl 3:1-82.

14. Borja RO. Equações preditivas para as pressões respiratórias máximas de crianças brasileiras [dissertação]. Natal: Universidade Federal do Rio Grande do Norte; 2011.
15. Freitas AF, Borja RO, Ferreira GMH, Nogueira PAMS, Mendonça KMPP. Predictive equations and values for maximal respiratory pressures in childhood and adolescence. Rev Paul Pediatr. 2011;29(4):656-62. http:// dx.doi.org/10.1590/S0103-05822011000400028

16. Schrader PC, Quajer H, Olivier ICW. Respiratory muscle force and ventilatory functions in adolescent. Eur Respir J. 1988;1:368-375.

17. Iuliano BA, Frutuoso MFP, Gambardella AMD. Anemia among adolescents according to sexual maturation. Rev Nutr. 2004;17(1):37-43. http://dx.doi.org/10.1590/ S1415-52732004000100004

18. Rodriguez RB. Metodologia da investigacion y escritura científica en clínica. Escuela Andaluza de Salud Pública; 1998.

19. Lima PMB, Farias RTFB, Carvalho ACA, Silva PNC, Ferraz Filho NA, Brito RF. Transcutaneous electrical nerve stimulation after coronary artery bypass graft surgery. Rev Bras Cir Cardiovasc. 2011;26(4):591-6. PMid:22358274. http://dx.doi.org/10.5935/1678-9741.20110049

20. Brasil. Ministério da Saúde. Incorporação da curva de crescimento da Organização Mundial da saúde de 2006 e 2007 nos SISVAN. [cited 2010 Nov 10]. Available from: http://www.nutricao.saude.gov.br/sisvan. php?conteudo=curvas_cresc_oms.

21. Harik-Khan RI, Wise RA, Fozard JL. Determinants of maximal inspiratory pressure: the Baltimore longitudinal study of aging. Am J Respir Crit Care Med. 1998;158:1459-64. PMid:9817693. http://dx.doi. org/10.1164/ajrccm.158.5.9712006

22. Esteves ASD, Ferraz M. Adaptation and validity of the ATS-DLD-78-C questionnaire for asthma diagnosis in children under 13 years of age. Braz Ped News. 1999;1:3-5.

23. Rodrigues JC, Cardieri JMA, Bussamra MHCF, Nakaie CMA, Almeida MB, Silva Filho LVF, et al. Provas de função pulmonar em crianças e adolescentes. J Pneumol. 2002; 28 Suppl 3:207-21.

24. Pereira CAC, Lemle A, Algranti E, Jansen JM, Valença LM, Nery LE, et al. I Consenso Brasileiro sobre Espirometria. J Pneumol. 1996;22:105-64.

25. American Thoracic Society - ATS/European Respiratory Society - ERS. ATS/ERS Statement on respiratory testing. Am J Respir Crit Care Med. 2002;166(4):518624. PMid:12186831. http://dx.doi.org/10.1164/ rccm.166.4.518

26. Software Anthro Plus. [cited 2010 Nov 10]. Available from: http://www.who.int/growthref/software.

27. Miller MR, Hankinson J, Brusasco V, Burgos F, Casaburi R, Coates A, et al. Standardisation of Spirometry. Eur Respir J. 2005;26:319-38. PMid:16055882. http://dx.doi. org/10.1183/09031936.05.00034805

28. Clanton TL, Diaz PT. Clinical Assessment of the Respiratory Muscles. Physical Therapy. 1995;75(11):98395. PMid:7480128.

29. Latorre MRDO. Medidas de risco e regressão logística. In: Massad E, Menezes RX, Silveira PSP, Ortega NRS. Métodos Quantitativos em Medicina. São Paulo: Manole; 2004. p. 337-50. 
30. Leech JÁ, Ghezzo H, Stevens D, Becklake MR. Respiratory and function in young adults. Am Rev Respir Dis. 1983;128:17-23. PMid:6870058.

31. Almeida CCB, Zeferrino AMB, Barros Filho AAB. Crescimento e função pulmonar. Rev Cienc Méd. 1999;8(3):85-92.

32. Aurora NS, Rochester DF. Respiratory muscle function in obesity and obesity hipoventilation syndrome. Clin Res. 1979;27:394A.

33. Kelly, TM, Jensen RL, Elliott CG, Crapo RO. Maximum respiratory pressures in morbidly obese subjects. Respiration. 1988;54:73-77. PMid:3231898. http://dx.doi. org/10.1159/000195504

34. Pedrozo MD, Trevisan ME, Moraes EZC. Respiratory muscular function of adolescents with overweight/obesity degree I and healthy. Fisioter Mov. 2007;20(4):137-41.

35. Rasslan Z, Saad RJ, Stirbulov R, Fabbri RMA, Lima CAC. Avaliação da função pulmonar na obesidade graus I e II. J Bras Pneumol. 2004; 30(6):508-14. http://dx.doi. org/10.1590/S1806-37132004000600004

36. Ray C, Sue DY, Bray G, Hansen JE, Wasserman K. Effects of obesity on respiratory function. Am Rev Respir Dis. 1983;128:501-69. PMid:6614644.

37. Fung KP, Lau SP, Chow OKW, Lee J, Wong TW. Efects of overweight on lung function. Arch Dis Child. 1990;65:512-5. PMid:2357090 PMCid:1792149. http://dx.doi.org/10.1136/adc.65.5.512

38. Santiago SQ, Silva MLP, Davidson J, Aristóteles LRCRB. Avaliação da força muscular respiratória em crianças e adolescentes com sobrepeso/obesos. Rev Paul Pediatr. 2008;26(2):146-50. http://dx.doi.org/10.1590/ S0103-05822008000200009

39. Kraemer WJ, Fry AC, Frykman PN, Conroy B, Hoffman J. Resistance training and youth. Pediatr Exerc Sci. 1989;1:336-50.

40. Koechlin C, Matecki S, Jaber S, Soulier N, Prefaut C, Ramonatxo M. Changes in respiratory muscle endurance during puberty. Pediatr Pulmonol. 2005;40:197-204. PMid:16032712. http://dx.doi.org/10.1002/ppul.20271
41. Evans JÁ, Whitelaw WA. The assessment of maximal respiratory mouth pressures in adults. Respir Care. 2009;54(10):1348-59. PMid:19796415.

42. Lyall RA, Donaldson N, Polkey MI, Heigh PN, Moxhan J. Respiratory muscle strehgth and ventilator failure in amyotrophic lateral sclerosis. Brain. 2003;124:2000-13. http://dx.doi.org/10.1093/brain/124.10.2000

43. Soliman MG, Higgins SE, El-Kabir DR, Davidson AC, Williams AJ, Howard RS. Non-invasive assessment of respiratory muscle strength in patients with previous poliomyelitis. Respir Med. 2005;99:121722. PMid:16140221. http://dx.doi.org/10.1016/j. rmed.2005.02.035

44. Fauroux B, Aubertin G, Clément A, Lofaso F, Bonora M. Which test may predict the need for noninvasive ventilation in children with neuromuscular disease? Respir Med. 2009;103:574-81. PMid:19036569. http://dx.doi. org/10.1016/j.rmed.2008.10.023

45. Silva SB, Viana ESR, Sousa MBC. Changes in peak ventilatory flow and respiratory strength during the menstrual cycle. Respir Physiol Neurobiol. 2006;150:21119. PMid:16476654. http://dx.doi.org/10.1016/j. resp.2005.03.001

46. Saaresranta S, Polo O. Hormones and breathing. Chest. 2002; 122: 2165-182. http://dx.doi.org/10.1378/ chest.122.6.2165

\section{Correspondence}

Karla Morganna Pereira Pinto de Mendonça

Universidade Federal do Rio Grande do Norte

Departamento de Fisioterapia

Campus Universitário

Av. Senador Salgado Filho, 3000, Lagoa Nova

CEP 59078-970, Natal, RN, Brazil

e-mail: kmorganna@ufrnet.br 